\title{
Renal agenesis, unilateral
}

INSERM

\section{Source}

INSERM. (1999). Orphanet: an online rare disease and orphan drug data base. Renal agenesis, unilateral. ORPHA:93100

Unilateral renal agenesis (URA) is a form of renal agenesis (see this term) characterized by the complete absence of development of one kidney accompanied by an absent ureter. 